\title{
From the Interdisciplinary Conference of AHLiST 2010 Conference IS/IT Program Chair
}

\author{
DOI:10.3991/IJIM.V5I3.1666
}

The Association of History, Literature, Science and Technology (AHLiST) 2010 is an organization established in 2008 by interdisciplinary researchers from the Cambridge University, Universidad Complutense de Madrid, Universidad Nebrija, Universidad Pontificia de Comillas, Purdue University, Biblioteca Histórica Marqués de Valdecilla and the company DENODO technologies.

The initial goals of this organization were for these interdisciplinary researchers to create an automatic transcription of manuscripts with Artificial Intelligence. The AHLiST organizers and researchers held its first interdisciplinary conference from June 23 to June 25, 2010 in Madrid, Spain to offer exciting opportunities for researchers and practitioners from different disciplines (Communications, Education, History, Literature, Science, Sociology, and IT/IS) to share research ideas, to promote future scholarly work, and to learn relationships among different disciplines.

It was a true globalized and multi-disciplined conference that offers networking with researchers in different areas, while enjoying the surroundings in Spain. For the 2010, nine tracks with 50 panels of different themes included 140 quality presentations including case studies, research progress, and completed papers. Only selected papers went through a blind review process with 2 or 3 reviewers for each paper.

The conference was organized by Purdue University, Universidad Complutense de Madrid, Universidad Nebrija, and St. Louis University in Madrid.

We invited five keynote speakers : Dr. Pedro Cátedra, Universidad de Salamanca, Dr. Roger Chartier, Collège de France, Dr. José María Díez Borque, Universidad Complutense de Madrid, Dr. Ángel Gómez Moreno, Universidad Complutense de Madrid, and Dr. Ronnie Wilbur, Purdue University

Among 140 presentations, the following selected five papers from IS/IT sessions introducing new technologies usage in healthcare, mobile technology, and education were selected to be presented in this special issue.

[1] D.J. McManus, H.H. Carr, B.M. Adams, "Global Telecommunications Security: Effects of Geomagnetic Disturbances", Int. Journal of Interactive Mobile Technologies, 5, 3, pp. 6-11, 2011, doi:10.3991/ijim.v5i3.1667

[2] Carlos A. Arévalo, Estela L. Muñoz, Juan M. Gómez, "A Software Tool to Visualize Verbal Protocols to Enhance Strategic and Metacognitive Abilities in Basic Programming", Int. Journal of Interactive Mobile Technologies, 5, 3, pp. 12-19, 2011, doi:10.3991/ijim.v5i3.1668

[3] U. Raja, D.J. McManus, J.M. Hardin, B.C. Haynes, “Collaborative Rural Healthcare Network: A Conceptual Model”, Int. Journal of Interactive Mobile Technologies, 5, 3, pp. 20-23, 2011, doi:10.3991/ijim.v5i3.1669

[4] Roland Schwald, "Interdisciplinary Approaches at Institutions of Higher Education: Teaching Information Systems Concepts to Students of Non-Computer Science Programs", Int. Journal of Interactive Mobile Technologies, 5, 3, pp. 24-31, doi:10.3991/ijim.v5i3.1670

[5] Debopam Acharya, Hyo-Joo Han, "Advances in Integrated Vehicle Health Monitoring Systems", Int. Journal of Interactive Mobile Technologies, 5, 3, pp. 32-37, doi:10.3991/ijim.v5i3.1671 
GUEST EDITORIAL

\section{ACHKNOWLEDGEMENT}

We thank committees including Distinguished Executive Board, Primary Advisory Board, Conference

Coordinators, and Chief Section Organizers from various research institutes in Europe and the United States.

\section{Directors:}

Song No, Director, Associate Dean of College of Liberal, Purdue University

Eugenio Bustos Gisbert, Co-Director, Catedrático de Filología Española, UCM

\section{Distinguished Executive Board:}

Dámaso López García, Decano, Facultad de Filología, Universidad Complutense

Irwin Weiser, Dean of College of Liberal Arts, Purdue University

Alberto López Rosado, Decano of Escuela Politécnica Superior, Universidad Nebrija

\section{Primary Advisory Board:}

Thomas J. Berndt (Associate Dean of Research, Purdue University)

Tom Case (Chair, Dept. of Information Systems, Georgia Southern University )

Attilio De Luca (Preside della Facoltà "Scuola Speciale per Archivisti e Bibliotecari")

Epícteto Díaz Navarro (Profesor Titular de Filología Española, UCM)

Paul Dixon (Professor of Spanish, Purdue University)

Patricia Hart (Professor of Spanish, Purdue University)

R. Douglas Hurt (Professor, Department Head, Department of History, Purdue University.)

Howard Mancing (Professor of Spanish, Purdue University.)

Nancy Peterson (Professor \& Interim Head, Department of English, Purdue University.)

Jeffery Siskind (Associate Professor of Electrical and Computer Engineering, Purdue University.)

Ronnie Wilbur (Professor and Chair of Linguistics program, Purdue University.)

José Raúl Vaquero Pulidor (Presidente de la Fundación Ciencias de la Documentación)

\section{Conference Coordinators:}

Yoonsoo Kim, Assistant Professor of Spanish, Purdue University.

Francisco García-Serrano, Professor of History, SLU-Madrid

\section{Chief Section Organizers:}

- History: Francisco García-Serrano Professor of History, SLU-Madrid

- Literature and Linquistics :Asunción López-Varela Prof. Titular de Filología Inglesa, UCM

- Science and Technology: Constantino Malagón, Prof. Titular de Ingeniería Informática, Universidad Nebrija and Hyo-Joo Han, Associate Professor of Information Systems, Georgia Southern University. 